\title{
12 Landscape character assessment and regional landscape strategy in the Azores, Portugal
}

\author{
Rosário Oliveira and Nuno Guiomar
}

\section{Introduction}

Fast and continuous landscape changes have been considered as one of the strongest drivers behind the loss of nature values, along with degradation and regimes of ecological disturbances that have evident impacts on economic activities (Olarieta et al., 2008; Nuissl et al., 2009). The need to preserve the diversity, identity and cultural heritage of landscapes and societal demand for sustainable development (Roca and Oliveira-Roca, 2007; van Eetvelde and Antrop, 2009a) has led to initiatives for inventorying, assessing and monitoring landscape dynamics (Meeus, 1995; Swanwick, 2002; Cancela d'Abreu et al., 2005). It has also improved landscape modelling based on future scenarios (van Berkel and Verburg, 2011).

Over the last decade, these concerns have allowed landscape character to be considered as a concept to support land use policies. Considering landscape features as distinctive characteristics, particular combinations of biophysical and anthropogenic components may lead to a recognisable pattern of elements and thereby create a specific landscape character (Swanwick, 2002; Jessel, 2006).

Stimulated by the European Landscape Convention (ELC), landscape character assessment has been developed as a methodological approach that identifies landscape either to better understand its components and how they interact or to integrate them in spatial planning, especially at the local level (Oliveira et al., 2011). Thus, countries such as Portugal that have ratified the Convention, legally recognise landscape as a fundamental element for their citizens' quality of life, in an attempt to define landscape policies that aim at landscape protection, management and planning. The ELC Art. 1, indeed, defines landscape policies as an 'expression by the competent public authorities of general principles, strategies and guidelines that permit the taking of specific measures aimed at the protection, management and planning of landscapes' (Council of Europe, 2000: 9).

This is the case of the Azores islands, where the Regional Government applied this definition of landscape policy at the regional level. However, island landscape evaluation is extremely complex due to its very particular dynamics, not only those related to geodynamic processes but also those arising from land use.

Moreover, landscape character assessment can be seen as a process to identify, describe and evaluate landscapes based on the presence and arrangement of landscape features (Makhzoumi and Pungetti, 1999), as well as on the recognition of the main forces of change. Furthermore, diverse approaches have been used for landscape assessment, both in methods and in applications for different purposes (Wascher, 


\section{Rosário Oliveira and Nuno Guiomar}

2005; van Eetvelde and Antrop, 2009a). For this reason, the authors of this chapter considered two different studies at two different times (2005 and 2012), making use of different methodological approaches.

Landscape character assessment may be influenced by diverse factors such as the scale of observation and the perception that each individual has of a landscape, according to their system of values and knowledge. This frequently leads to a process that is strongly biased. Spatial relations are complex, and they include continuity and spatial heterogeneity. Thus, identifying landscape units with relative homogeneity is dependent not only on how it ranks each variable in the analysis but also on its distribution, which is more or less homogeneous. This chapter aims to present the fundamental aspects of a new method in island landscape character assessment, useful for setting up landscape policy design in the Azores.

\section{Azores landscape and its biophysical context}

The Azores is an isolated archipelago located in the North Atlantic Ocean, and it is the most westerly point of the European continent - about 1,600 km from the Portuguese mainland and 1,900 km from Newfoundland (Figure 12.1). The nine islands of the archipelago span $615 \mathrm{~km}$ alongside a WNW-ESE axis, with a total surface area of $2,322 \mathrm{~km}^{2}$, and are divided into three groups: the western group (Flores and Corvo); the central group (Faial, Pico, S. Jorge, Terceira and Graciosa); and the eastern group (S. Miguel and S. Maria, plus the Formigas islets) (Figure 12.1). All of the islands show a volcanic genesis, having emerged along ocean floor fracture zones where the North American, Eurasian and African tectonic plates meet at a triple junction (Azevedo and Ferreira, 2006) that accounts for particular dynamic processes related to seismovolcanic episodes.

The climate is predominantly temperate oceanic and strongly influenced by the elevation and occurrence of cloudy and misty conditions. The relative humidity is high and could reach $95 \%$ at high-altitude native forests. The mean annual temperature ranges from $19^{\circ} \mathrm{C}$ on the plateaus to about $9^{\circ} \mathrm{C}$ on the mountain tops and shows low thermal amplitude throughout the year. Mean annual rainfall varies from $750 \mathrm{~mm}$ to more than $3,000 \mathrm{~mm}$ per year, increasing with the altitude and from east to west. Frequent storms come from the west, but the islands are also influenced by the Leste, a series of sandstorms that originate in North Africa (Reis et al., 2002).

Soils are generally young andisols derived from pyroclastic materials under udic and mesic environments, whose characteristics depend on the age, nature of the parent material and climatic conditions (Pinheiro et al., 2004). The natural vegetation includes diverse communities, namely coastal vegetation, coastal and inland wetlands, meadows, peat bogs and native forest. The native Azorean vegetation is Laurisilva, a humid and dense evergreen broadleaf and microphyllous laurel type forest (Dias, 2001). Dominant species include Myrica faya, Laurus azorica, Ilex perado subsp. azorica, Juniperus brevifolia, Myrsine africana, Calluna vulgaris, Vaccinium cylindraceum Erica azorica, Taxus sp. and Sphagnum spp., the latter considered a Tertiary relic (Sjögren, 2000; Dias, 2001). This type of vegetation covered the islands when they were discovered in the early fifteenth century. Since then, vegetation has undergone deep and irreversible changes essentially for cereal crops, pasture and forestry. It is currently affected by the invasive behaviour demonstrated by some of the species introduced (Schaefer et al., 2011). 

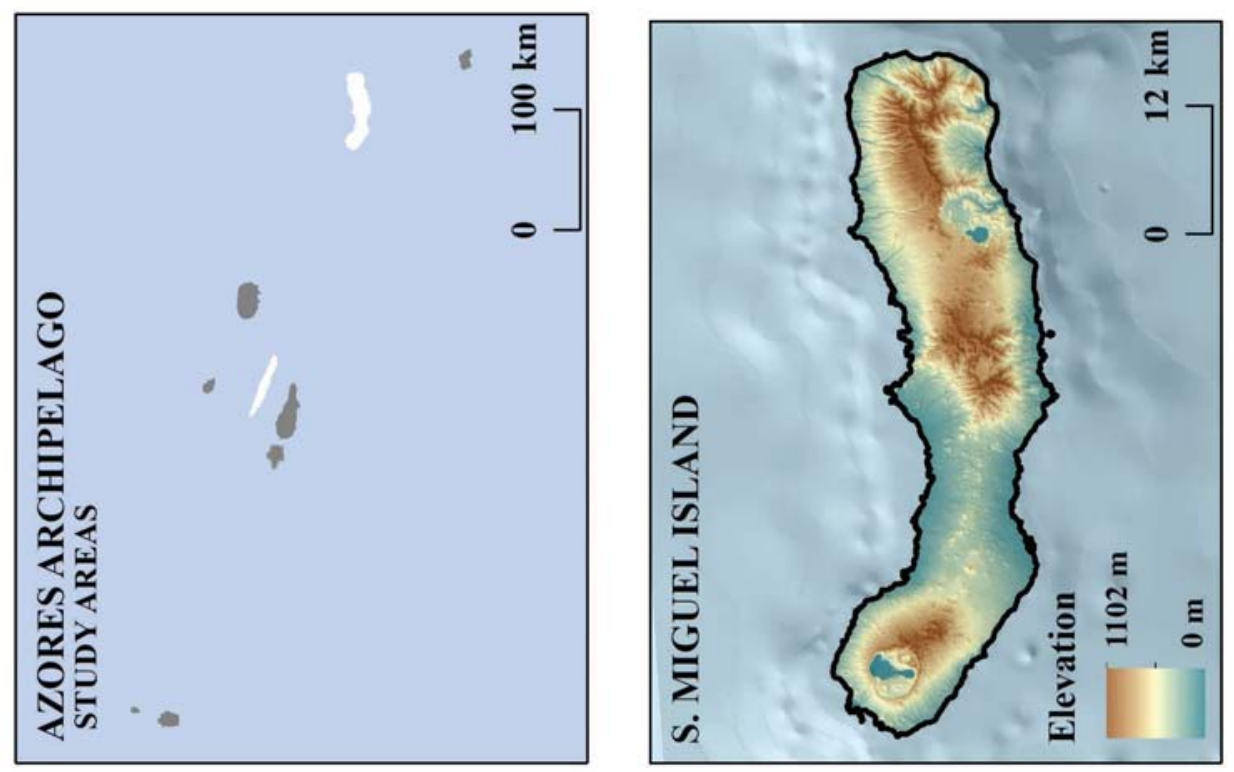

(4)
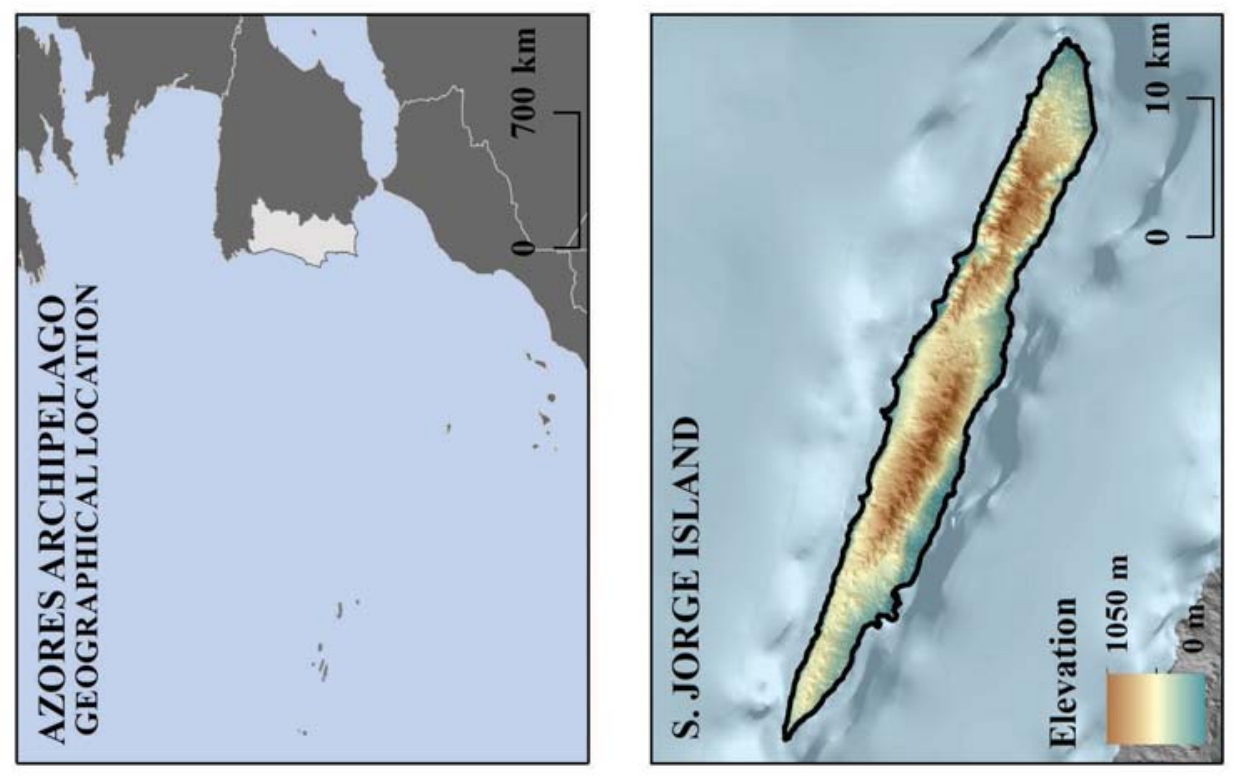

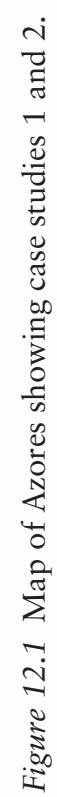




\section{Study areas, data and geoprocessing}

In order to test a new methodology for landscape character assessment and to compare the results obtained from a prior study (Study 1), two study areas have been considered for Study 2, here described: the islands of S. Miguel and S. Jorge in the Azores (Figure 12.1). The updated limits of S. Miguel and S. Jorge landscape units were obtained through a methodology that had integrated spatial analysis and geographical modelling processes in geographic information systems and cluster analysis (spatial and non-spatial clustering).

Initially, the process consisted of an exploratory analysis of the available and official spatial information provided by the Regional Government. Topo to Raster module (ArcGIS 10) was employed to compute a hydrologically correct digital elevation model (DEM) with a cell size of $10 \mathrm{~m}$, using a procedure based on the algorithm developed by Hutchinson (1989). Slope and aspect were computed according to Horn's method (Horn, 1981). The land cover map from regional forest inventory, with a scale of 1:25,000, was generalised to 6 land cover classes: built-up areas, agricultural areas, forests, shrubland, bare rocks and water bodies. The land suitability map was also used ( 5 classes), as well as the building density (number $/ \mathrm{km}^{2}$ ).

To reduce the computational effort, the centroids of a regular grid with 10 ha were extracted, and then alternate rows and columns were selected (3,702 sample sizes for S. Miguel Island and 1,199 for S. Jorge Island). The value of each variable was linked to each sample point by spatial join (vectorial data) and extraction processes in which the value of the cell centre was used (raster data).

\section{Landscape character assessment: non-spatial clustering, spatial interpolation and comparison}

Since the weight of each variable on the landscape character is not spatially uniform, two spatial contagion variables were generated using the Spatial Statistics module (ArcGIS 10.0) and including Local Moran's I (Anselin, 1995) in order to identify spatial clusters of features with attribute values similar in magnitude (Mitchell, 2005).

In addition, the Getis-Ord statistic (Getis and Ord, 1992; Ord and Getis, 1995) was performed to evaluate each feature within the context of neighbouring features in order to recognise spatial hot spots. The results of spatial dependence patterns were used in a cluster analysis with the Scrucca (2005) method and Statistica ${ }^{\text {TM }} 7.0$ to compute the distances between observations and clusters.

The final landscape boundaries resulted from cartographic processes, fieldwork and expert-computed analysis using a spherical semivariogram model (Goovaerts, 1999; van Groenigen, 2000). The results, summarised in Figure 12.2, outlined 17 landscape units (LU) for S. Miguel and 11 landscape units for S. Jorge. Then Study 1 and Study 2 were compared, with the major differences found in the south of the island of $S$. Miguel.

Despite differences in the two studies, the comparative results revealed a spatial coherence between the two moments (Figure 12.2). The differences between the results from Study 1 and the model implemented in this chapter (Study 2) can be associated for different reasons. However, the most plausible, given the high dynamics in the studied islands and highlighted in Study 1 (Cancela d'Abreu et al., 2005), may be related to changes in land use. 


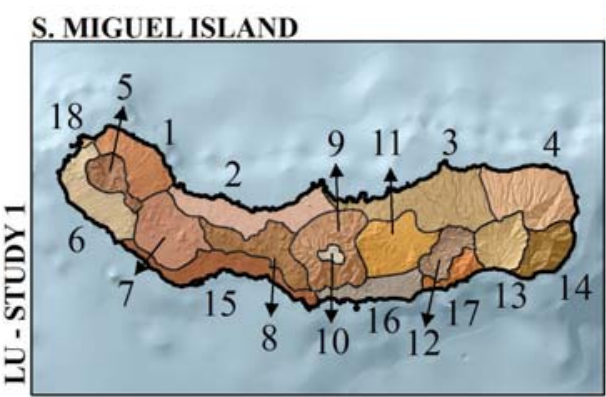

S. JORGE ISLAND

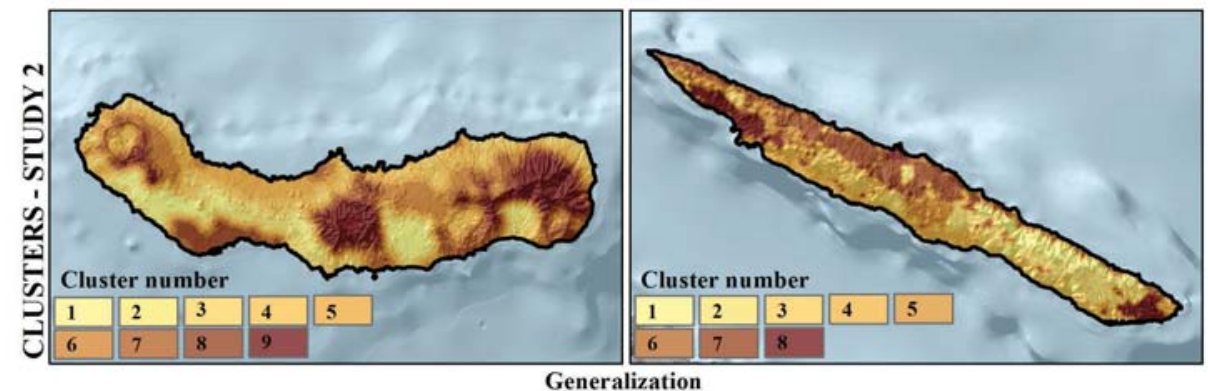

Field work and expert analysis
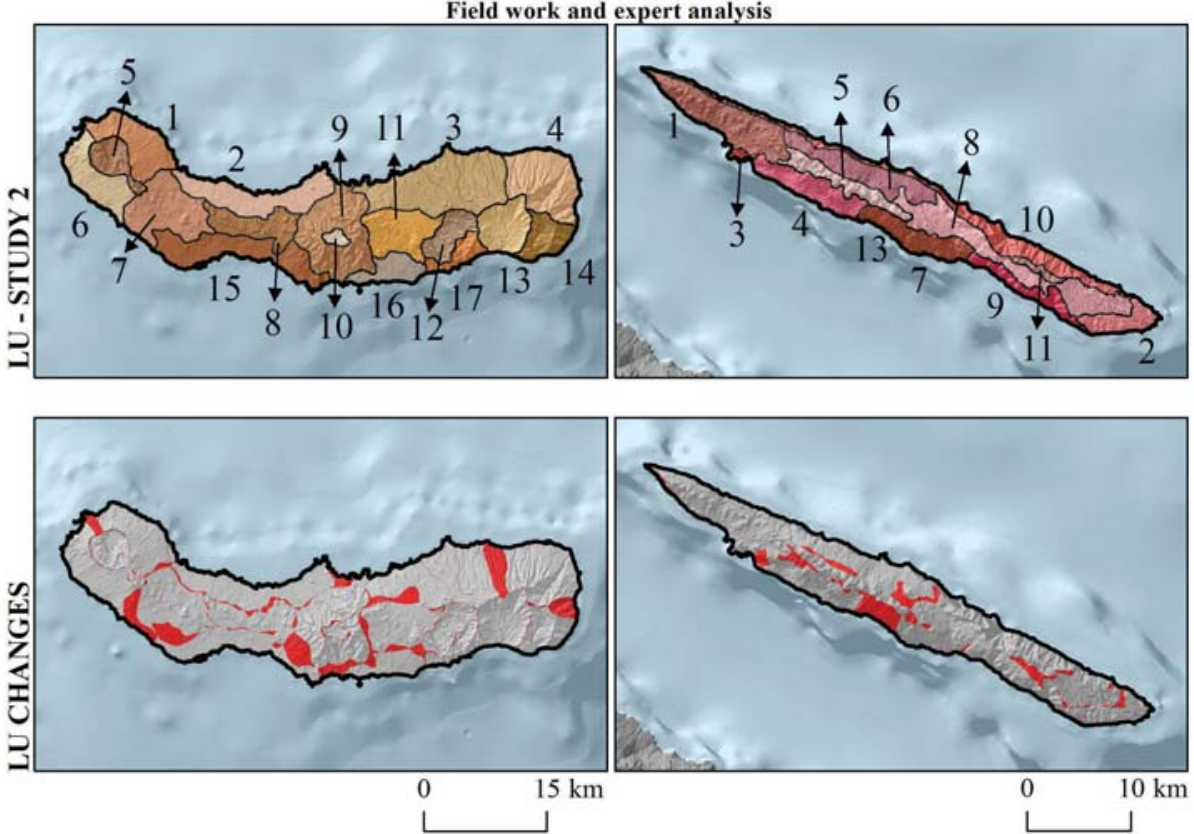

Figure 12.2 Results from landscape character assessment and map comparison between studies 1 and 2. 
In Study 1, furthermore, the landscape units resulted from criteria developed by the project team. The authors assumed substantial subjectivity in the process and reported that other experts may have obtained different results. It also noted the fuzzy transition between landscape units and the strong dynamics of change in the islands, forwarding the results to a well defined temporal context.

\section{A tool for landscape classification}

Geographic information systems (GIS) and remote sensing-based methods were used in previous studies in order to define and characterise spatial units (Haines-Young, 1992; Lioubimtseva and Defourny, 1999; Bastian, 2000; Kim and Pauleit, 2007). However, most traditional landscape classifications are based on expert knowledge (Haase, 1989; Meeus et al., 1990), and despite the identifiable divisions that can be observed, they cannot be extrapolated statistically. Groom et al. (2006) also concluded that the majority of the classifications were elaborated in a top-down approach and highlighted the limitations of the automated derivations of landscape character types.

GIS and remote sensing processes, combined with statistical classification techniques (for example, clustering), resulted in a significant classification of landscape character types (Blankson and Green, 1991; Bunce et al., 1996; Cain et al., 1997; Metzger et al., 2005; Jongman et al., 2006; Owen et al., 2006; van Eetvelde and Antrop, 2009b). Bunce et al. (1996) used GIS and multivariate statistics to argue a land classification for a strategic ecological survey. GIS-based processes, combined with clustering techniques, were conducted by Metzger et al. (2005) and Jongman et al. (2006) to produce a statistical stratification of the European environment. Owen et al. (2006) used fuzzy clustering to derive eight urban classes in an urban landscape, reducing the previous dimensionality of the land cover dataset through principal component analysis. Van Eetvelde and Antrop (2009b) used a method that combines sequentially parametric and holistic approaches at two scale levels, in order to define the new landscape typology of Belgium, fitting into the European Landscape Convention to typify contemporary landscapes from a transregional and transborder perspective. Jellema et al. (2009) presented a methodology for landscape character assessment using a regiongrowing algorithm (image segmentation technique to divide or segment an image into regions or spatially continuous clusters) and concluded that the new approach was more consistent than the expert classification.

Our approach combines GIS spatial analysis and two clustering approaches, one spatial (local clustering) and the other non-spatial (global clustering), to evaluate the landscape character of S. Jorge and S. Miguel islands (Figures 12.3-12.8). In our best model, all variables, with the exception of the density of the outliers, represent hot and cold spots, namely a clustering of high and low values respectively, computed by Getis-Ord statistic. Zhu et al. (2010) used the Getis-Ord Gi statistics to allow identification of areas with statistically significant concentrations of high landscape values, not subject to the arbitrary setting of a density threshold for class boundary definition.

The differences between the results from the study conducted by Cancela d'Abreu et al. (2005) and the model implemented in this chapter were not relevant. However, the most plausible reasons to explain the differences, given the high dynamics of the islands studied in the prior study, may be related to land use changes.

Despite the high consistency of the results between the two studies and a proportion of the difference that can be explained by changes in land use, there are certainly 


\section{Proof}

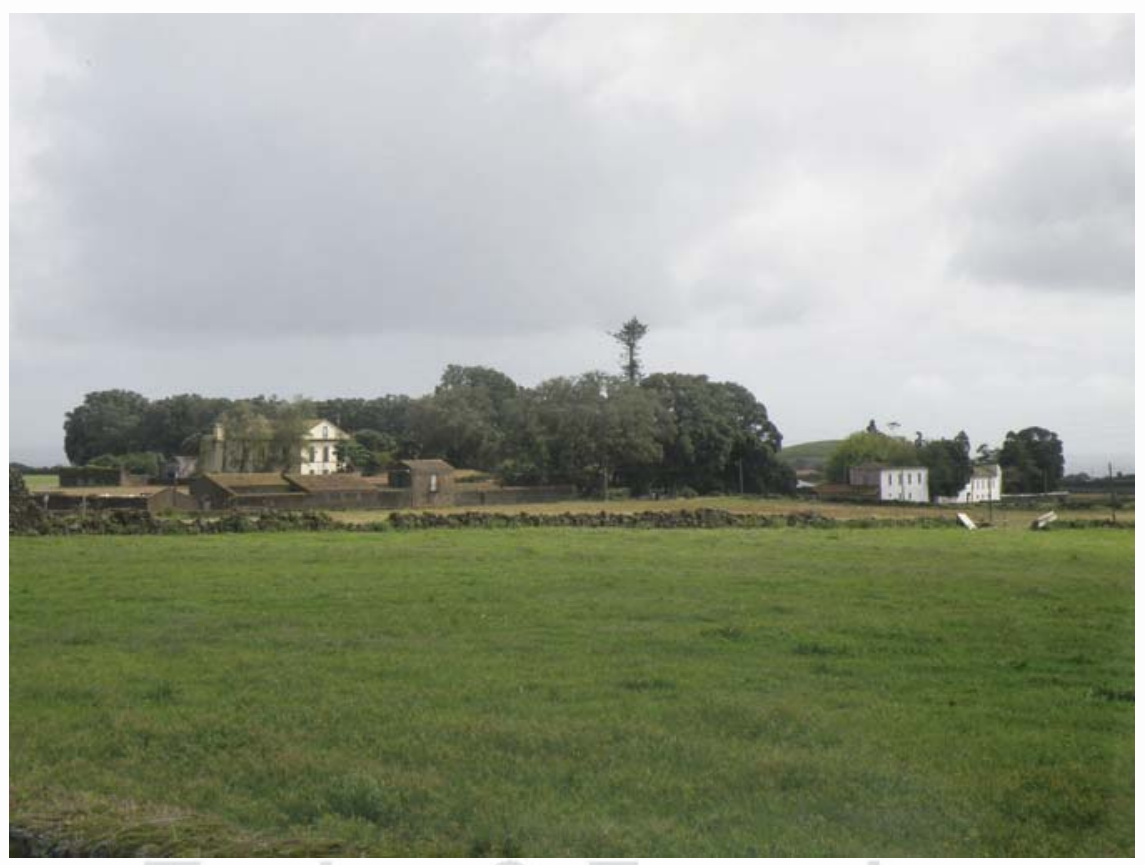

Figure 12.3 Traditional farm in S. Miguel. $\quad$ II

$\oplus$

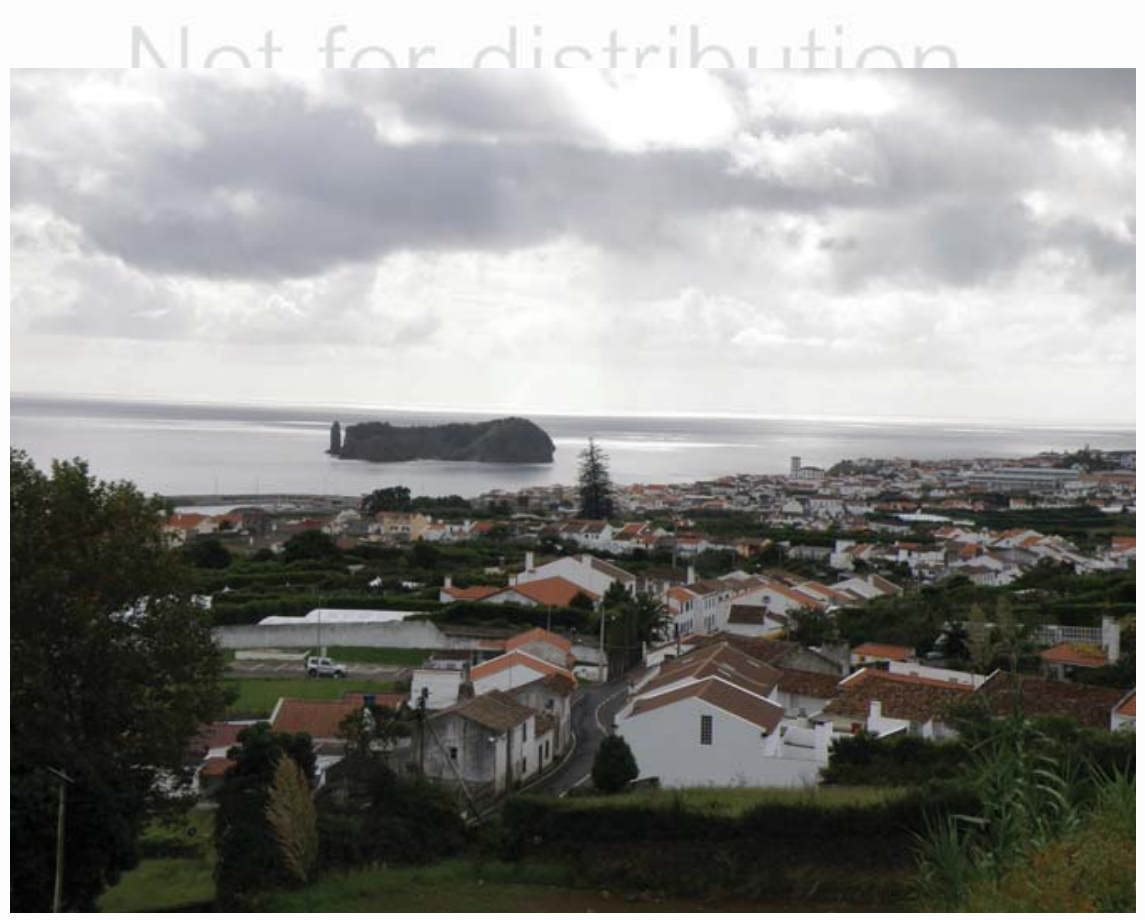

Figure 12.4 Vila Franca do Campo in S. Miguel.

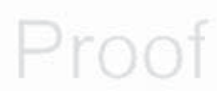




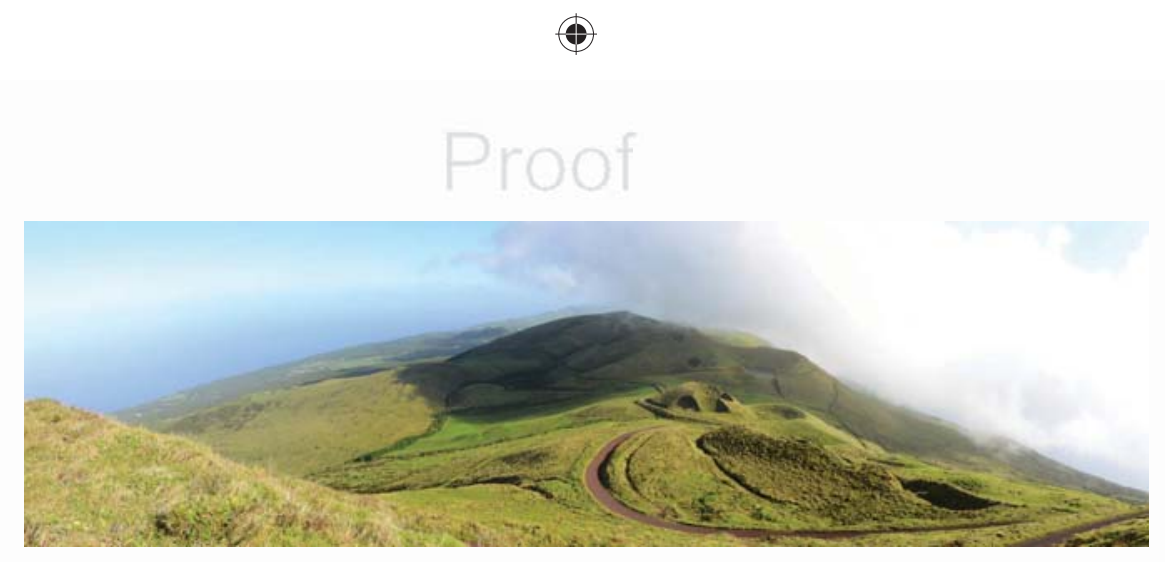

Figure 12.5 Highland in S. Jorge.

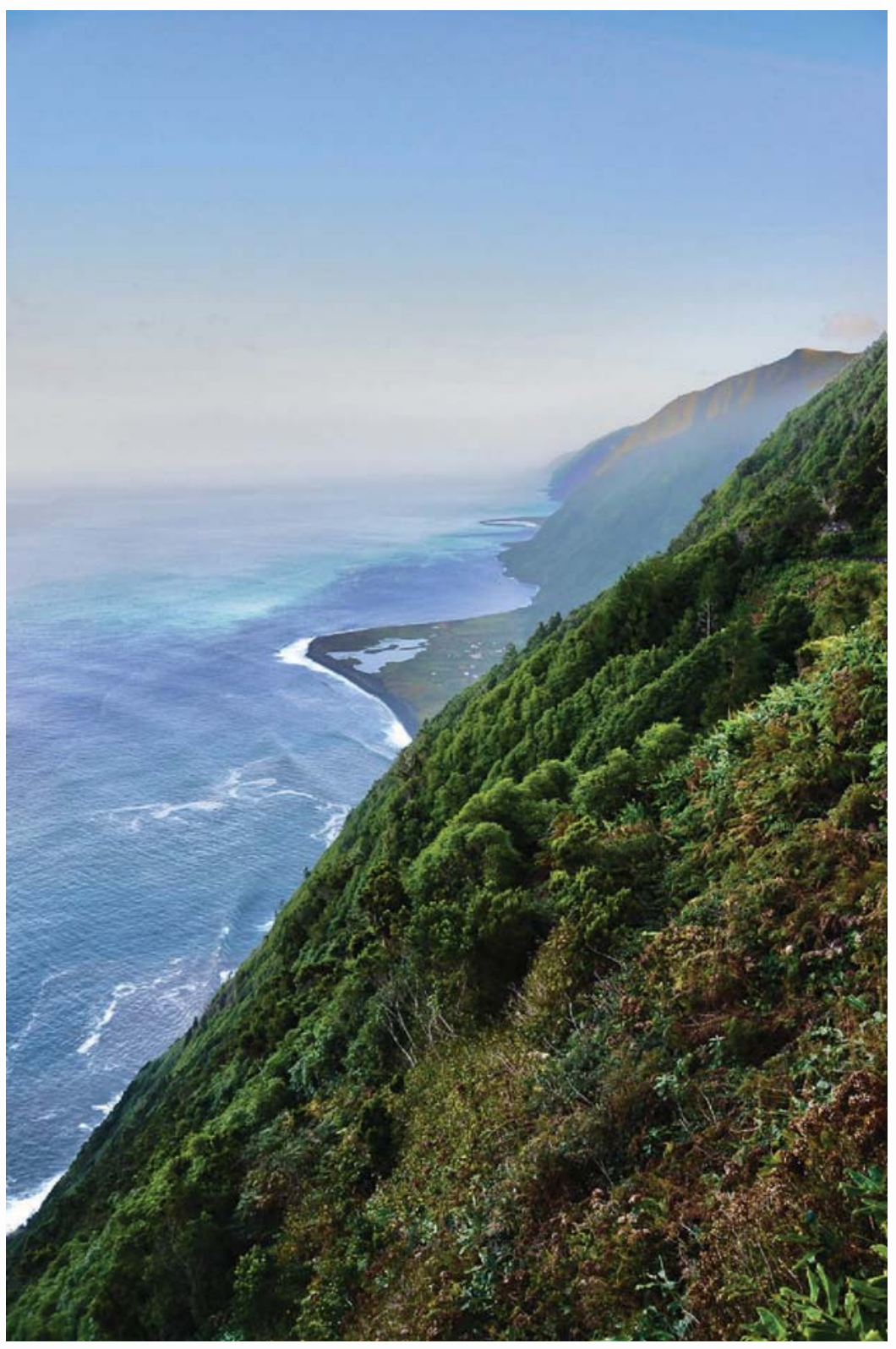

Figure 12.6 Northern hillside in S. Jorge and its Fajãs on the toe of cliffs as tongues of land reaching up through the sea. 


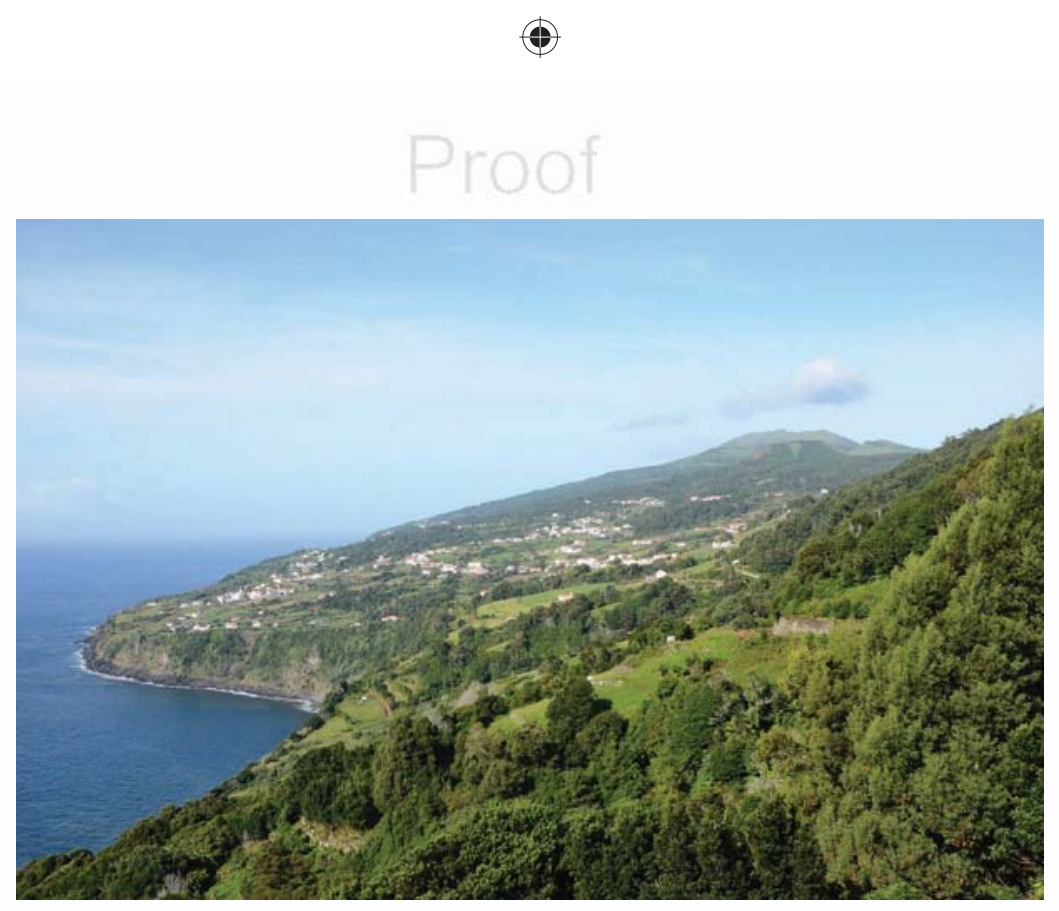

Figure 12.7 General view of the southern hillside in S. Jorge.

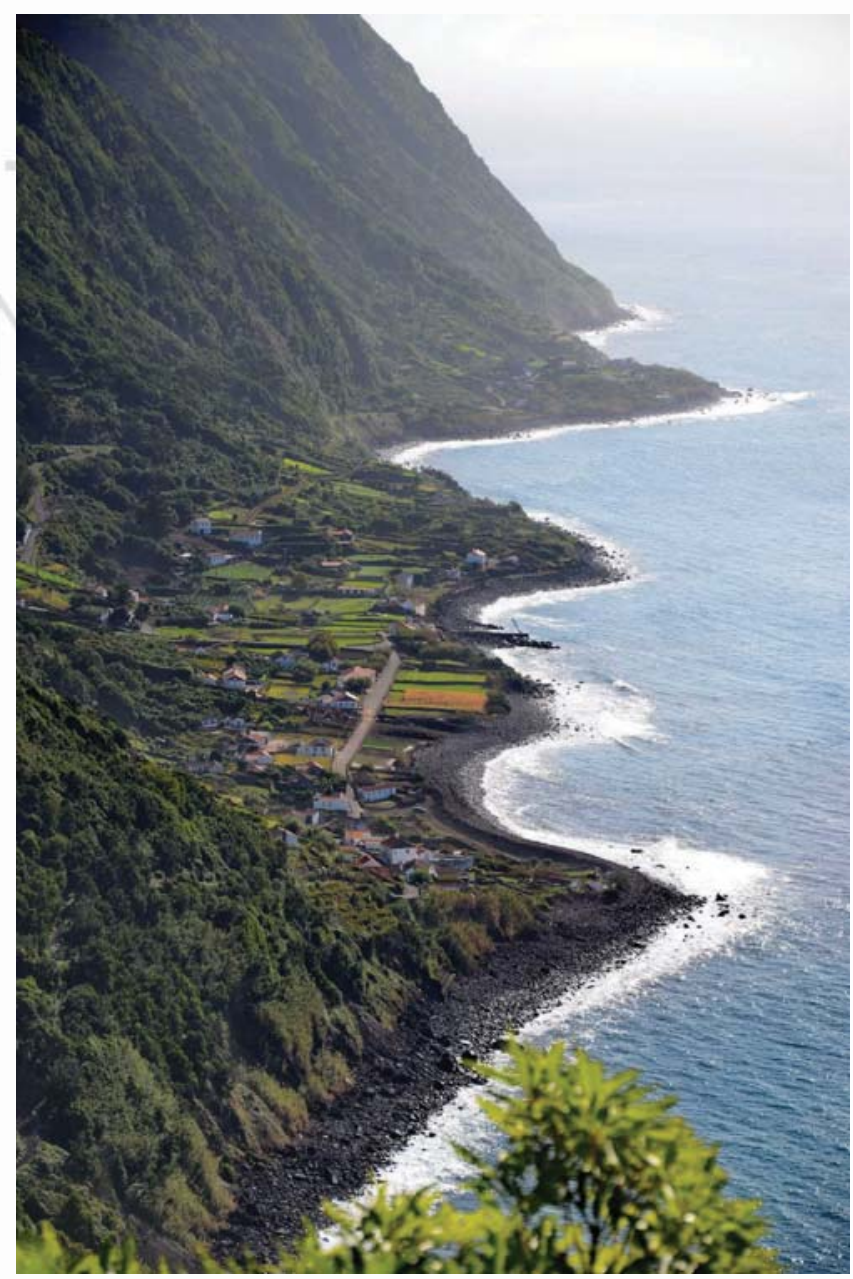

Figure 12.8 Southern hillside and its Fajãs in S. Jorge.

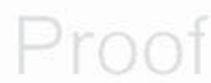




\section{Rosário Oliveira and Nuno Guiomar}

differences in units related to methodological approaches. Also noteworthy are some differences resulting from the automatic adjustment of the landscape boundaries to relief variations (e.g. ridges) and from using an interactive process to build the digital elevation model that interpolates a hydrologically correct raster surface. In fact, there are also differences in the geoprocessing methods used to compute the input variables. The relative influence of these factors will be addressed in future work.

\section{Conclusions}

Regarding the consistency of the results, it is possible to extract two main conclusions. The first is that the application of this methodology should be considered for the other seven islands as relevant in order to update information on the most significant land use dynamics that have taken place over the last decade and on the way their impact may affect landscape quality regarding economic activities such as tourism, cultural identity and biodiversity, among other aspects of sustainability. This information must be seen as crucial and has to be taken into account in the decision-making process of spatial planning and landscape management, especially following the guidelines of the regional landscape policy that have been designed in the context of the same project that framed the methodology presented here.

The second is that the implementation of the ELC can proceed before this update is ready, since where the most recent and significant dynamics have happened, there have been only a few concise changes of landscape units in the islands.

In this way, the integration between landscape character assessment, as a tool to identify landscape coherency and a participatory approach for the definition of landscape quality objectives in each landscape unit, will be the basis for the implementation of the ELC at a local level. This approach has already been experienced in two landscape units, one in S. Miguel and the other in S. Jorge, as case studies that have shown how to integrate the contribution of local people in defining the landscape they wish to have in the future and as a model for collaborative landscape management.

\section{References}

Anselin, L. (1995). Local indicators of spatial association - LISA. Geographical Analysis, 27 (2): 93-115.

Azevedo, J.M.M. and Ferreira, M.R.P. (2006). The volcanotectonic evolution of Flores Island, Azores (Portugal). Journal of Volcanology and Geothermal Research, 156: 90-102.

Bastian, O. (2000). Landscape classification in Saxony (Germany): A tool for holistic regional planning. Landscape and Urban Planning, 50: 145-155.

Berkel van, D.B. and Verburg, P.H. (2011). Sensitising rural policy: Assessing spatial variation in rural development options for Europe. Land Use Policy, 28 (3): 447-459.

Blankson, E.J. and Green, B.H. (1991). Use of landscape classification as an essential prerequisite to landscape evaluation. Landscape and Urban Planning, 21: 149-162.

Bunce, R.G.H., Barr, C.J., Clarke, R.T., Howard, D.C. and Lane, A.M.J. (1996). Land classification for strategic ecological survey. Journal of Environmental Management, 47: 37-60.

Cain, D.H., Riitters, K. and Orvis, K. (1997). A multi-scale analysis of landscape statistics. Landscape Ecology, 12: 199-212.

Cancela D'abreu, A., Moreira, J.M. and Oliveira, M.R. (2005). Livro das Paisagens dos Açores: Contributos para a Identificação e Caracterização das Paisagens dos Açores. Ponta Delgada: Sram Drotrh.

Council of Europe (2000). European Landscape Convention. Strasbourg: Council of Europe. 
Dias, E. (2001). Ecologia e classificação da vegetação natural dos Açores. Angra do Heró́smo: Universidade dos Açores.

Eetvelde van, V. and Antrop, M. (2009a). Indicators for assessing changing landscape character of cultural landscapes in Flanders (Belgium). Land Use Policy, 26: 901-910.

Eetvelde van, V. and Antrop, M. (2009b). A stepwise multi-scaled landscape typology and characterisation for trans-regional integration, applied on the federal state of Belgium. Landscape and Urban Planning, 91: 160-170.

Getis, A. and Ord, J.K. (1992). The analysis of spatial association by use of distance statistics. Geographical Analysis, 24: 189-206.

Goovaerts, P. (1999). Geostatistics in soil science: state-of-the-art and perspectives. Geoderma, 89: 1-45.

Groom, G., Wascher, D., Potschin, M. and Haines-Young, R. (2006). Landscape character assessments and fellow travellers across Europe. In: R.G.H. Bunce and R.H.G. Jongman (eds). Landscape Ecology in the Mediterranean: Inside and Outside Approaches. Proceedings of the European IALE Congress 2005. Faro: IALE, 221-231.

Haase, G. (1989). Medium scale landscape classification in the German Democratic Republic. Landscape Ecology, 3: 29-41.

Haines-Young, R.H. (1992). The use of remotely-sensed satellite imagery for landscape classification in Wales (U.K.). Landscape Ecology, 7: 253-274.

Horn, B.K.P. (1981). Hill shading and the reflectance map. Proceedings of the IEEE, 69: 14-47.

Hutchinson, M.F. (1989). A new procedure for gridding elevation and stream line data with automatic removal of spurious pits. Journal of Hydrology, 106: 211-232.

Jellema, A., Stobbelaar, D.J., Groot, J.C.J. and Rossing, W.A.H. (2009). Landscape character assessment using region growing techniques in geographical information systems. Journal of Environmental Management, 90: S161-S174.

Jessel, B. (2006). Elements, characteristics and character - information functions of landscapes in terms of indicators. Ecological Indicators, 6 (1): 153-167.

Jongman, R.H.G., Bunce, R.G.H., Metzger, M.J., Mücher, C.A., Howard, D.C. and Mateus, V.L. (2006). Objectives and applications of a statistical environmental stratification of Europe. Landscape Ecology, 21: 409-419.

Kim, K.-H. and Pauleit, S. (2007). Landscape character, biodiversity and land-use planning: the case of Kwangju city region, South Korea. Land Use Policy, 24: 264-274.

Lioubimtseva, E. and Defourny, P. (1999). GIS-based landscape classification and mapping of European Russia. Landscape and Urban Planning, 44: 63-75.

Makhzoumi, J. and Pungetti, G. (1999). Ecological Landscape Design and Planning: The Mediterranean Context. London: Spon.

Meeus, J.H.A. (1995). Pan-European landscapes. Landscape and Urban Planning, 31: 57-79.

Meeus, J.H.A., Wijermans, M.P. and Vroom, M.J. (1990). Agricultural landscapes in Europe and their transformation. Landscape and Urban Planning, 18: 289-352.

Metzger, M.J., Bunce, R.G.H, Jongman, R.H.G., Mücher, C.A. and Watkins, J.W. (2005). A climatic stratification of the environment of Europe. Global Ecology and Biogeography, 14: 549-563.

Mitchell, A. (2005). The ESRI Guide to GIS Analysis, Vol. 2. Redlands: ESRI Press.

Nuissl, H., Haaseb, D., Lanzendorf, M. and Wittmer, H. (2009). Environmental impact assessment of urban land-use transitions: a context-sensitive approach. Land Use Policy, 26: 414-424.

Olarieta, J.R., Rodríguez-Valle, F.L. and Tello, E. (2008). Preserving and destroying soils, transforming landscapes: soils and land-use changes in the Vallès County (Catalunya, Spain) 1853-2004. Land Use Policy, 25: 474-484.

Oliveira, R., Cancela D'abreu, A., Botelho, M.J. and Afonso, M. (2011). A Paisagem na Revisão dos PDM: Orientações para a Implementação da Convenção Europeia da Paisagem. Lisboa: DGOTDU.

Ord, J.K. and Getis, A. (1995). Local spatial autocorrelation statistics: Distributional issues and an application. Geographical Analysis, 27 (4): 286-306. 


\section{Rosário Oliveira and Nuno Guiomar}

Owen, S.M., Mackenzie, R., Bunce, R.G.H., Stewart, H., Donovan, R.G., Stark, G. and Hewitt, C.N. (2006). Urban land classification and its uncertainties using principal component and cluster analysis: a case study for the UK West Midlands. Landscape and Urban Planning, 78: 311-321.

Pinheiro, J., Salguero, M.T. and Rodriguez, A. (2004). Genesis of placic horizon in Andisols from Terceira Island (Azores-Portugal). Catena, 56: 85-94.

Reis, M.A., Oliveira, O.R., Alves, L.C., Rita, E.M.C., Rodrigues, F., Fialho, P., Pio, C.A, Freitas, M.C. and Soares, J.C. (2002). Comparison of continental Portugal and Azores Islands aerosol during a Sahara dust storm. Nuclear Instruments and Methods in Physics Research, B189: 272-278.

Roca, Z. and Oliveira-Roca, M.N. (2007). Affirmation of territorial identity: A development policy issue. Land Use Policy, 24: 434-442.

Schaefer, H., Olivier, J.H., Silva, L., Barraclough, T. and Savolainen, V. (2011). Testing Darwin's naturalization hypothesis in the Azores. Ecology Letters, 14 (4): 389-396.

Scrucca, L. (2005). Clustering multivariate spatial data based on local measures of spatial autocorrelation. Quaderni del Dipartimento di Economia, Finanza e Statistica, 20: 1-11.

Sjögren, E. (2000). Aspects on the biogeography of Macaronesia from a botanical point of view. Arquipélago, S2A: 1-9.

Swanwick, C. (2002). Landscape Character Assessment - Guidance for England and Scotland. Edinburgh: Countryside Agency, Cheltenham and Scottish Natural Heritage.

van Groenigen, J.W. (2000). The influence of variogram parameters on optimal sampling schemes for mapping by kriging. Geoderma, 97: 223-236.

Wascher, D. (ed) (2005). European Landscape Character Areas: Typologies, Cartography and Indicators for the Assessment of Sustainable Landscapes. Final Report as Deliverable form the EU's Accompanying Measure Project European Landscape Character Assessment Initiative (ELCAI). Alterra Report 1254.

Zhu, X., Pfueller, S., Whitelaw, P. and Winter, C. (2010). Spatial differentiation of landscape values in the Murray River Region of Victoria, Australia. Environmental Management, 45 (5): 896-911. 